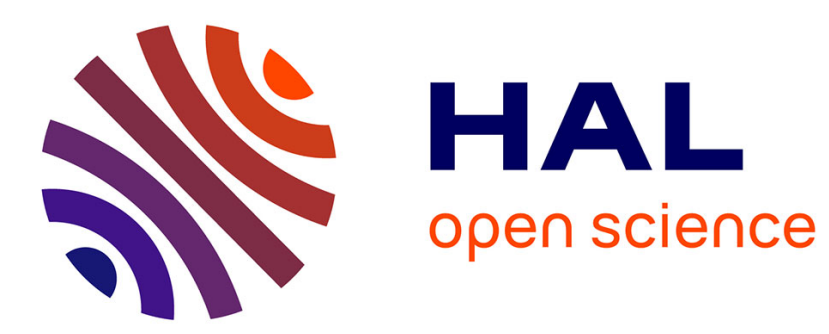

\title{
An automated pressure evaluation system (APES) for determining the fermentation characteristics of ruminant feeds
}

Dr Davies, Mk Theodorou, J Baughan, Ae Brooks, Jr Newbold

\section{- To cite this version:}

Dr Davies, Mk Theodorou, J Baughan, Ae Brooks, Jr Newbold. An automated pressure evaluation system (APES) for determining the fermentation characteristics of ruminant feeds. Annales de zootechnie, 1995, 44 (Suppl1), pp.36-36. hal-00889200

\section{HAL Id: hal-00889200 https://hal.science/hal-00889200}

Submitted on 1 Jan 1995

HAL is a multi-disciplinary open access archive for the deposit and dissemination of scientific research documents, whether they are published or not. The documents may come from teaching and research institutions in France or abroad, or from public or private research centers.
L'archive ouverte pluridisciplinaire HAL, est destinée au dépôt et à la diffusion de documents scientifiques de niveau recherche, publiés ou non, émanant des établissements d'enseignement et de recherche français ou étrangers, des laboratoires publics ou privés. 


\title{
An automated pressure evaluation system (APES) for determining the fermentation characteristics of ruminant feeds
}

\author{
DR Davies 1, MK Theodorou 1, J Baughan 1, AE Brooks 1, JR Newbold 2 \\ IIGER, Plas Gogerddan, Aberystwyth, Dyted, SY23 3EB; \\ 2BOCM-PAULS, PO Box 39, 47 Key Street, Ipswich, IP4 1BX, UK
}

\begin{abstract}
Many approaches have been taken to determine the nutritive value of ruminant feeds, most of which rely upon the measurement of end-points of digestibility and ignore the importance the kinetics of the process. A new method which enables the determination of rates of gas accumulation from in vitro fermentations was described recently (Theodorou et al, 1994, Anim Feed Sci Technol, 48, 185 - 197). The procedure uses a pressure transducer to determine gas accumulation during the fermentation of feeds in substrate-limited batch cultures inoculated with rumen digesta. One problem with the technique is the need for frequent readings during the initial $(30-40 \mathrm{~h})$ fermentation period, thus making it labour intensive. Experiments with different silages using the manual pressure transducer indicated that although differences could be detected, they were small when comparing different silages incubated over a long ( 5 d) fermentation period. The new automated technique overcomes this limitation, is more sensitive and allows a better description of the initial $(8 \mathrm{~h})$ rate of fermentation.
\end{abstract}

The new system consists of 50 gas-tight culture bottles ( $\mathrm{ca} 140 \mathrm{ml}$ ), each fitted with a pressure sensor and solenoid valve linked to a $\mathrm{PC}$ for continuous (real-time) monitoring of all bottles. In experiments, the bottles are charged with ca $90 \mathrm{ml}$ of medium, $0.5-1.5 \mathrm{~g}$ of substrate and $10 \mathrm{ml}$ of rumen microbial inoculum. During fermentation, each of the inline solenoid valves are activated at a given gas pressure (ca $0.9 \mathrm{psi}$ ) causing them to open momentarily and release the accumulated gas. The number of vents and time between each vent is automatically recorded for each bottle, thus enabling construction of gas accumulation profiles.

The automated system was assessed by comparing it to the manual gas production technique using pure cellulose as the substrate. The volume of gas produced $(\mathrm{ml})$ versus time (h) profiles for both systems were very similar. The rate of gas production was almost identical with the time taken to reach half the final gas volume being ca 37 and $40 \mathrm{~h}$ respectively for the automated and manual methods. The overall final gas pool size after $100 \mathrm{~h}$ was also similar at 230 and $260 \mathrm{ml}$ respectively for the automated and manual systems.

In conclusion the automated technique has great potential because it can be used routinely and with continuous monitoring there is reduced labour input compared to the manual method. So as a tool for studies concerned with the nutritive value of feeds and feed supplements, this equipment shows considerable promise. 